\title{
Do calcifying nanoparticles really contain I6S rDNA?
}

This article was published in the following Dove Press journal:

International Journal of Nanomedicine

17 September 2012

Number of times this article has been viewed

Farooq A Shiekh

Aix-Marseille Université, URMITE, UMR, CNRS 7278,

IRD 198, Marseille, France
Correspondence: Farooq A Shiekh URMITE, Faculté de Médecine,

27 Bd Jean Moulin, I 3385 Marseille Cedex 5, France

Tel +33491324480

Fax +3349I3877 72

Email shiekh.fa@gmail.com

\section{Dear editor}

With great interest, I read a recent article published in the International Journal of Nanomedicine by Guo et al. ${ }^{1}$ This study involved an analysis of calcifying nanoparticles to determine the presence of unique 16S rDNA. Nanoparticles that have since been isolated from biological samples have properties that appear to be consistent with a novel life form, including "self-replication". However, despite a large body of intriguing and suggestive evidence, the true biological nature of nanoparticles has been elusive, and in the past decade this subject has spurred one of the biggest controversies in modern microbiology. ${ }^{2}$ First, the results published in the Proceedings of the National Academy of Sciences by Cisar et al reached a completely opposite conclusion to the original assertion by Kajander and Ciftçioglu, which identified nanobacteria as living organisms. ${ }^{3,4}$ In addition, a closer look at the $16 \mathrm{~S}$ rDNA sequences previously ascribed to so-called nanobacterial species showed that they are virtually identical to those of a notorious contaminating microorganism, Phyllobacterium mysinacearum. Second, after this report, multiple evidence-based studies were conducted in order to better understand the actual biological composition and self-propagation of nanobacteria..$^{5-7}$ None of these findings are conclusive; however, biological insights of this mystery are now emerging.

The study comprehensively succeeded in demonstrating evidence of the widespread occurrence of calcific disease, a hallmark feature of calcifying nanoparticles. Nevertheless, unlike previous reports,,$^{3,7,8}$ the study raises the intriguing possibility that these special particles contain nucleic acids. Particularly, the authors isolated DNA from decalcified nanoparticles retrieved from placental calcification tissues. Notably, in a well-defined experiment, the amplified genes showed $83 \%$ sequence identity with previously reported 16S rDNA for nanobacteria (EMBL X98419). Thus, an important issue not addressed by this study is that definitive proof, or "need-to-know" questions, regarding "DNA" must be answered with convincing evidence. However, no significant (or supplementary) data were provided to better describe the special methods used to isolate nanoparticle DNA from nanobacteria. Furthermore, limited information is available regarding the maintenance of their nanoparticle culture; nanoparticle culturing methods are critical for avoiding opportunistic bacterial contamination.

In summary, this field has suffered from important limitations and misinterpretations in demonstrating nanobacteria as novel organisms. Thus, an alternative, although in no ways less interesting, understanding is that calcifying nanoparticles 
are self-propagating and of protein-based particulate nature, or that they are "reminiscent of prion particles." These observations are considered to be important contributing factors for microcalcification. ${ }^{6,9}$ However, no consensus has been reached.

\section{Disclosure}

The author reports no conflicts of interest in this work.

\section{References}

1. Guo Y, Zhang D, Lu H, Luo S, Shen X. Association between calcifying nanoparticles and placental calcification. Int J Nanomedicine. 2012;7: $1679-1686$.

2. Abbott A. Researchers fail to find signs of life in 'living' particles. Nature. 2000;408(6811):394.
3. Cisar JO, Xu DQ, Thompson J, Swaim W, Hu L, Kopecko DJ. An alternative interpretation of nanobacteria-induced biomineralization. Proc Natl Acad Sci U S A. 2000;97(21):11511-11515.

4. Kajander EO, Ciftçioglu N. Nanobacteria: an alternative mechanism for pathogenic intra- and extracellular calcification and stone formation. Proc Natl Acad Sci U S A. 1998;95(14):8274-8279.

5. Raoult D, Drancourt M, Azza S, et al. Nanobacteria are mineralo fetuin complexes. PLoS Pathog. 2008;4(2):e41.

6. Shiekh FA, Charlesworth JE, Kim SH, et al. Proteomic evaluation of biological nanoparticles isolated from human kidney stones and calcified arteries. Acta Biomater. 2010;6(10):4065-4072.

7. Young JD, Martel J. The rise and fall of nanobacteria. Sci Am. 2010;302(1): 52-59.

8. Abbott A. Battle lines drawn between 'nanobacteria' researchers. Nature. 1999;401(6749):105.

9. Jahnen-Dechent W, Heiss A, Schafer C, Ketteler M. Fetuin-A regulation of calcified matrix metabolism. Circ Res. 2011;108(12):1494-1509.
International Journal of Nanomedicine

\section{Publish your work in this journal}

The International Journal of Nanomedicine is an international, peerreviewed journal focusing on the application of nanotechnology in diagnostics, therapeutics, and drug delivery systems throughout the biomedical field. This journal is indexed on PubMed Central, MedLine, CAS, SciSearch ${ }^{\circledR}$, Current Contents ${ }^{\circledR} /$ Clinical Medicine,

\section{Dovepress}

Journal Citation Reports/Science Edition, EMBase, Scopus and the Elsevier Bibliographic databases. The manuscript management system is completely online and includes a very quick and fair peer-review system, which is all easy to use. Visit http://www.dovepress.com/ testimonials.php to read real quotes from published authors. 